\title{
Development of Learning Methods for Student Center Learning with Problem Based Learning in Block 4.c Midwifery Care in High Risk Childbirth and Postpartum
}

\author{
Yulizawati ${ }^{1}$, Miranie Safaringga ${ }^{2}$, Ulfa Farrah Lisa $^{3}$, Rafika Oktofa ${ }^{4}$ \\ \{yulizawati@yahoo.co.id ${ }^{1}$, miraniesafaringga@med.unand.ac.id ${ }^{2}$, ulfafarrahlisa@med.unand.ac.id ${ }^{3}$ \} \\ Midwifery Program Faculty of Medicine, Universitas Andalas, Padang, Indonesia
}

\begin{abstract}
Achievement of the learning objectives of a student with the method of learning problem based learning (PBL), can be influenced by the results of extracting their peer information in small groups because the information obtained by students will be discussed to perfect the knowledge gained. This study applies a small group discussion (SGD) and tutorial in the PBL method. The results of the study, there was an increase in the value of students before and after treatment with a value of $p=0,000$, and there was a difference in the grades of students in 2017 and 2016, where the grades of students in 2017 were better than in 2016, with $p=0.001$. The results of the interview that students prefer the SGD method over discussion in large classes, students feel better understand the discussion material, each group member is more active and gives their opinions according to the theory of the book or journal that has been studied, lecturer attention to each student is greater, so students are very enthusiastic in studying the material and discussing it. PBL method with SGD is very effective to be applied in learning to increase the activeness, interactive, learning motivation, and critical thinking of students.
\end{abstract}

Keywords: Learning Methods, Problem Based Learning

\section{Introduction}

Block 4.C titled midwifery care in childbirth and childbirth with high risk, is a block that must be studied by semester IV students in the Midwifery Bachelor Program of the Faculty of Medicine, Andalas University. Students who take lessons in this Course Block provide opportunities for students to understand concepts, changes in childbirth and childbirth with high risk. By understanding this concept students are expected to be able to manage midwifery care in labor and childbirth with high risk according to the needs of mothers and in accordance with the authority of midwives. Thus mastery of the material in Block $4 \mathrm{C}$ is important, because it will provide provisions for students in providing midwifery care in childbirth and childbirth with high quality risk.

Block 4.C, entitled midwifery care in childbirth and childbirth with high risk, is a block that must be studied by fourth semester students in the Midwifery Bachelor Program of the Faculty of Medicine, Andalas University. Students who take lessons in this Course Block provide opportunities for students to understand concepts, changes in childbirth and childbirth with high risk. By understanding this concept students are expected to be able to manage 
midwifery care in labor and childbirth with high risk according to the needs of mothers and in accordance with the authority of midwives. Thus mastery of the material in Block $4 \mathrm{C}$ is important, because it will provide provisions for students in providing midwifery care in childbirth and childbirth with high quality risk.

Learning is prepared in the form of lectures by experts in the appropriate fields, tutorial discussions, and skills training in the laboratory. This block runs for 6 weeks, each module will be discussed every week, so this block will discuss 6 modules. In addition to expert lectures, students will carry out clinical skills training. Every week there will be a plenary discussion on the topic adjusted to the lecture and tutorial material. At the end of the block, the $4 \mathrm{C}$ block theory learning evaluation will take the form of a written test. The contribution of this block to the competencies / learning outcomes in the curriculum of the study program is that students are able to master 29 main competencies, 9 supporting competencies and 1 specific competency as a midwife who is spread in 7 (seven) Midwife competency areas. Innovation of learning methods developed in support of learning achievements in the form of introductory lectures, tutorials, small group discussions, skills labs, expert lectures, practical work, plenary discussions, independent learning.

At the end of the module, students were able to explain dystocia caused by fetal factors, dystocia due to birth canal factors, dystocia caused by maternal factors, bleeding during the puerperium and infections and lactation problems during the puerperium.

Contribution of blocks to or learning outcomes in the study program curriculum Includes the achievement of competency areas 1-7 namely: legal ethics and patient safety, effective communication, personal development and professionalism, scientific foundation for obstetric practice, clinical skills in midwifery practice, health promotion and counseling and management and leadership.

\section{Research Methods and Development of Learning Methods}

The research sample was all female students of the Midwifery Faculty of Medicine, Andalas University 2017, year semester IV semester IV. This research uses quasiexperimental with pretest posttest control group design.

\section{Development of problem-based Learning Methods (PBL)}

Problem-based learning (problem-based learning / PBL) is a learning strategy for students learning together in a small group through two main learning activities, namely small group discussions facilitated by a tutor and independent learning.

PBL is a form of student center learning (SCL) learning method that is more directed and structured. In contrast to pure SCL, students are given the discretion in determining the scope of material learned in accordance with their interests. In PBL learning the scope of learning is more focused and specific. The scope of learning in PBL is based on specific learning objectives detailed in the curriculum. The amount of time spent on the PBL process is also more limited than the amount of time spent on pure SCL. In pure SCL, students are given the discretion in determining the amount of time they need to complete their inquiry, while in PBL students must complete the achievement of their learning goals within the time frame determined by the educational institution. In pure SCL, students can work individually based on their respective interests, so they are not dependent on the learning outcomes of other students. Whereas in PBL, the achievement of learning objectives by a student, can be 
influenced by the results of extracting their peer information in small groups because the information obtained by each student will be discussed to perfect the knowledge they have gained.

Problem solving is not the only goal of the PBL process. Problems or scenarios are used as stimulus learning processes to increase knowledge and understanding of learning goals that have been set in the curriculum. So PBL can also be used to facilitate students in gaining basic knowledge. Thus, PBL not only facilitates the acquisition of problem solving skills, but also the acquisition of knowledge and understanding, and several other soft skills skills such as communication, teamwork, independence and responsibility for learning, sharing information and respecting others.

\section{Planning:}

a. The lecturer identifies, sets, and groups learning objectives that will be discussed at each PBL learning session.

b. The lecturer arranges, chooses or looks for the right scenario to stimulate students to learn the learning objectives that have been set for each PBL session. Scenarios can be in the form of cases, fragments of films, images, news footage and others.

c. The lecturer estimates the schedule for implementing the 1st PBL tutorial, the amount of independent learning time needed to achieve all the learning objectives that have been set for the PBL session and the schedule for the 2nd PBL tutorial.

d. The lecturer prepares a rubric for evaluating student activities during the tutorial process which consists of attendance, creativity, relevance, attitudes and other assessment points that are deemed necessary.

e. The lecturer divides students into small groups that can consist of 5-10 students per group, each group ideally being facilitated by a tutor.

f. PBL tutors do not have to be lecturers in the related fields discussed in the scenario. PBL tutors can be anyone who can carry out the role, with the following roles:

1) Help PBL group leaders maintain group dynamics.

2) Ensuring the group is able to complete the learning objectives that have been set.

3) Ensuring that all students have done their assignments correctly.

4) Helps suggest a format for presentation of independent learning outcomes that is appropriate for group members.

5) Encourage students to evaluate their understanding of the material by asking questions, explaining the material in their own words with pictures and schematics.

6) Give feedback to students about their participation in the tutorial process and about achieving learning objectives.

\section{Implementation:}

PBL tutorials are carried out in various ways. The PBL model in the Midwifery Study Program at the Faculty of Medicine at Andalas University is seven jumps. For each module, students can be given a handbook containing scenarios, while learning resources or materials are given at the right time according to the progress of the tutorial. The steps for implementing PBL are as follows:

a. Students are allowed to choose seats to sit on chairs that have been arranged in such a way that facilitates group discussion. 
b. Students choose a group leader who will act as the moderator of the discussion, and two clerks to record the discussion on a sheet of paper and on the board. The role is played for each scenario. The appropriate flip chart or whiteboard must be used to record the discussion process.

c. At the beginning of the session, depending on the type of scenario, one student reads the scenario to all group members or each student reads the scenario individually. If the trigger or scenario is a real patient in the ward, clinic or operating room then students may be asked to take a clinical history or identify abnormal physical signs before the group moves to the tutorial room.

The stages of seven jumps are as follows:

Step 1 : Identifying and explaining incomprehensible terms encountered in the scenario, the scribe notes a list of terms that remain inexplicable after discussion.

Step 2 : Defining the problem or problem to be discussed, students may have different views about the problem, but all must be considered, the scribe notes the agreed list of problems.

Step 3 : "Brainstorming" is a session to discuss issues that have been agreed to be discussed. Students discuss possible explanations or hypotheses that will explain the problem that was specified in step 2, using the knowledge they already have before. Students work together by using each other's knowledge and identifying areas of knowledge that have not been properly explained or are not enough. The clerk records all the results of the discussion.

Step 4 : Review the discussion reviews in steps 2 and 3. Then organize the explanation into a tentative solution, which is restructured in the form of a scheme.

Step 5 : Formulate learning objectives, the group reaches consensus on learning objectives, the tutor ensures that learning objectives are focused, attainable, comprehensive and appropriate.

Step 6 : Self study. All students gather information related to each learning goal. This step is done outside of the PBL tutorial. Lecturers or tutors need to give sufficient time for students to do independent learning so that all learning objectives are achieved.

Step 7 : The group will gather again for discussion (2nd tutorial discussion). Students share and discuss their independent learning outcomes. Tutors evaluate student learning outcomes.

\section{Development of Student Assessment}

Development of student assessment systems which include: Process assessment, Result assessment, Selection of assessment techniques according to competency level 


\section{Results and Discussion}

Table 1. Comparison of 2016 and 2017 students' knowledge

\begin{tabular}{llllll}
\hline \multirow{2}{*}{ Value Range } & Force 2016 & \multicolumn{3}{l}{ Force 2017 } & P value \\
\cline { 2 - 5 } & F & $\%$ & F & $\%$ & \\
\hline $85-100$ & 0 & 0 & 0 & 0 & \\
$80-84$ & 0 & 0 & 0 & 0 & \\
$75-79$ & 33 & 6 & 7 & 16 & \\
$70-74$ & 12 & 23 & 19 & 42 & 0,001 \\
$65-69$ & 22 & 42 & 17 & 38 & \\
$60-64$ & 10 & 19 & 1 & 2 & \\
$55-59$ & 3 & 6 & 0 & 0 & \\
$50-54$ & 2 & 4 & 1 & 2 & \\
\hline
\end{tabular}

Table 2. Comparison of 2017 students' knowledge between before and after class action research (CAR)

\begin{tabular}{llllll}
\hline \multirow{2}{*}{ Value Range } & Pretest & \multicolumn{3}{c}{ Posttest } & \multirow{2}{*}{ P value } \\
\cline { 2 - 4 } & F & $\%$ & F & $\%$ & \\
\hline $85-100$ & 0 & 0 & 0 & 0 & \\
$80-84$ & 1 & 2 & 9 & 20 & \\
$75-79$ & 1 & 2 & 16 & 36 & \\
$70-74$ & 6 & 13 & 14 & 31 & \\
$65-69$ & 8 & 18 & 4 & 9 & \\
$60-64$ & 5 & 11 & 1 & 2 & \\
$55-59$ & 9 & 20 & 0 & 0 & \\
$50-54$ & 15 & 33 & 1 & 2 & \\
\hline
\end{tabular}

The calculation results show that the majority of students in 2016 have a range of values between $65-95,42 \%$ of 53 people. Then the same study was conducted on the 2017 class of students, it was found that the majority of students had a range of 70-74, which was $42 \%$ of 45 people. After conducting statistical tests with the Mann Whitney test it was found that there were significant differences with the value of $\mathrm{P}=0.001$, namely the value of the class of 2017 that uses problem-based learning methods is better than the class of 2016.

The calculation results before applying the Student Center Learning (STL) learning method with the problem based learning (PBL) approach, obtained the majority of students in the range 55-59 with a total of 9 people (20\%) whereas after being given treatment the student scores increased by the majority in the range of $75-79$ namely 16 people (36\%). After doing statistical tests with Wilcoxon test found a significant difference with a value of $P=0,000$, namely the value of the post test force using the problem based learning method is better than the pre test value.

2017 class students have used the revised curriculum development referring to the midwifery professional education curriculum of the Indonesian Midwifery Education Association (AIPKIND), where the study material is more in-depth and focused which covers the study of dystocia caused by fetal factors, dystocia due to birth canal factors, dystocia caused by maternal factors, bleeding during the puerperium and infection and lactation problems in the puerperium.

Students of 2017 and 2016 class together use the Student Center Learning (STL) learning method with the problem based learning (PBL) approach, namely by using several methods, including tutorials, plenary, topic discussion, independent learning, practicum and 
introductory lectures. But what is different in this study is that the class of 2017 uses the Small Group Discussion (SGD) method in learning topic discussion, where students consist of 8-10 people and 1 lecturer facilitator, whereas in the 2016 class uses a large class system where students are divided into 5 groups and 1 facilitator.

The results of interviews with the class of 2017 students, it was found that students prefer the small group discussion method over discussions in large classes, where students feel better understand the discussion material, each group member is more active and gives their opinion according to the theory of books or journals that have been studied. . Students also said that the attention of lecturers to each student was greater, so students were very enthusiastic in studying the material and discussing it.

This research is in line with the results of Lutfiasari D \& Prasetyanti DK's research, there is an influence of the use of problem-based learning methods on partograph filling skills. PBL learning methods can be one of the alternative learning methods in the subchapter partographs in the Midwifery and Newborn Baby Care subjects. [1]

Renityas Research, NN, there is a significant difference with the different test results $(\mathrm{P}=$ 0.014) between student learning participation using problem based learning models with class group discussions on pregnancy midwifery care courses. Where PBL models the level of learning participation is better than class group discussions, then Problem Based Learning is effective in increasing student learning participation. [2]

Problem-based learning is a learning model that challenges students to "learn how to learn", work in groups or small group discussions (SGD) to find solutions to real-world problems. The problem given is used to find solutions to real-world problems. The problem given is used to bind students to curiosity in the intended learning. Problems are given to students, before students learn concepts or materials relating to problems that must be solved. [3]

The main objective of PBL is not to convey a large amount of knowledge to students, but rather to develop critical thinking skills and problem solving abilities and the same time develop the ability of students to actively build their own knowledge. PBL is also intended to develop students' learning independence and social skills. Learning independence and social skills can be formed when students collaborate to identify information, strategies and learning resources that are relevant for solving problems. [4]

Problem based learning has clear procedures for engaging students to identify problems. 6 steps of learning strategies based on problems which are then called problem solving methods, namely: 1) Formulating the problem, namely the steps of students in learning

\section{Conclusions}

In the assessment, with the integration of knowledge assessment, there was an increase in the 2017 Force 4C Block.

In the assessment before and after the action, obtained an increase in the value of knowledge between before and after treatment.

Students prefer the small group discussion method over discussions in large classes, students feel better understand the discussion material, each group member is more active and gives their opinions according to the theory of the book or journal that has been studied and the lecturer attention to each student is greater, so students are very enthusiastic in studying the material and discussing it. 


\section{References}

[1] Lutfiasari D \& Prasetyanti DK. 2016. Penggunaan Metode Pembelajaran Problem Based Learning Terhadap Ketrampilan Pengisian Partograf Pada Mahasiswa Semester III Di Prodi Kebidanan (D III) Universitas Kadiri.

[2] Renityas, NN. 2015. Efektifitas Model Problem Based Learning Terhadap Tingkat Partisipasi Belajar Pada Mata Kuliah Asuhan Kebidanan Kehamilan Pada Program Diploma. Jurnal Ners dan Kebidanan, Volume 2, No.1, April 2015. DOI: 10.26699/Inj.v2i!.ART.p092-094.

[3] Daryanto. 2014. Pendekatan Pembelajaran Saintifik Kurikulum 2013. Yogyakarta: Gava Media.

[4] Hosnan. 2014. Pendekatan Saintifik dan Kontekstual Dalam Pembelajaran Abad 21 Kunci Sukses Implementasi Kurikulum 2013. Jakarta: Ghalia Indonesia.

[5] Sanjaya, Wina. 2006. Strategi Pembelajaran Berorientasi Standar Proses Pendidikan. Jakarta: Kencana Prenada Media Group.

[6] Azizah, SUN. 2017, Efektivitas Strategi Pembelajaran Small Group Discussion Terhadap Prestasi Belajar Siswa Pada Mata Pelajaran Pai Kelas Viii Di Smp Negeri 27 Surakarta Tahun Pelajaran 2016/2017. Skripsi. Program Studi Pendidikan Agama Islam Fakultas Ilmu Tarbiyah Dan Keguruan Institut Agama Islam Negeri Surakarta

[7] Bahri, Syaiful dkk. 2010. Strategi Belajar Mengajar. Jakarta: Rineka Cipta.

[8] Sharmila SR, Mungal SU, More SR. Developing competencies of medical students using group discussion as TL method. IOSR J Dent Med Sci. 2014;13:24-7.

[9] Sajjad S. Effective teaching methods at higher education level. Pak J Spec Educ. 2010;11:29-43.

[10] Gopalakrishnan P, Swati Patki, Varghese SS, Harsha CH, Antony R. Effectiveness of different methods of education among first year medical students in Central Kerala. Int J Med Pharm Sci. 2014;5:01-4.

[11] Annamalai N, Manivel R, and Palanisamy R. 2015. Small group discussion: Students perspectives. Int J Appl Basic Med Res. 2015 Aug; 5(Suppl 1): S18-S20. doi: 10.4103/2229-516X.162257. PMCID: PMC4552057. PMID: 26380202

[12] [Sood R, Adkoli BV. Medical education in India - Problems and prospectus. J Indian Acad Clin Med. 2000;1:210-2.

[13] Medical Council of India. Vision. 2015. [Last accessed on 2012 Jan 07]. Available from: http://www.mciindia.org/tools/announcement/MCI-booklet.pdf . 